\title{
EVALUATION OF ANTIBACTERIAL AND HAEMOLYTIC ACTIVITY OF PHYTOCHEMICALS FROM FRESHWATER MICROALGA, EUGLENA VIRIDIS (EHREN)
}

\author{
JYOTIRMAYEE PRADHAN ${ }^{1}$, BASANTA KUMAR DAS ${ }^{2}$, SWAGATIKA SAHU ${ }^{3}$
}

${ }^{1}$ Department of Zoology, KKS Womens College, Balasore, Odisha, ${ }^{2}$ ICAR-Central Inland Fisheries Research Institute, Barrackpore, Kolkata, ${ }^{3} \mathrm{KVK}$, Bhanjanagar, Odisha

Email: jyotirmayee_sahani@yahoo.com

Received: 06 Jul 2018 Revised and Accepted: 14 Aug 2018

\begin{abstract}
Objective: The main aim of this research work was to evaluate the antibacterial and haemolytic activities of different extracts of Euglena viridis (E. viridis), a freshwater microalga.

Methods: The solvent extraction has been followed by a preliminary screening of phytochemicals. The ethanolic extract, $\mathrm{Eu}(\mathrm{EtOH}) \mathrm{was}$ chromatographed on a silica gel column. The column was eluted with hexane and then with ethyl acetate/hexane mixtures of increasing polarity, 16 fractions (Ef1-Ef16) were collected and grouped according to their TLC (Thin layer chromatography). Antibacterial activities of different fractions of E. viridis against Pseudomonas putida (P. putida) ATCC49828, P. aeruginosa MTCC 35672, Aeromonas hydrophila (A. hydrophila) MTCC 646, ATCC 49140, eleven strains of Staphylococcus aureus (S. aureus) and thirteen strains of Flavobacterium columnare (F. columnare) was done using disc diffusion methods. Haemolytic activity was carried out by using blood agar plate method. The MIC (Minimum inhibitory concentration) values of active fractions were determined by the broth dilution method.
\end{abstract}

Results: The results showed that the Eu(EtOH) poses significantly ( $\mathrm{p} \leq 0.5)$ higher zone of inhibition $(14.0 \pm 0.28,13.5 \pm 0.28 \mathrm{~mm})$ against FLV8 and FLV9 respectively. Three strains of Flavobacterium (FLV5, FLV6 and FLV10) were highly sensitive (zone size, $17 \mathrm{~mm}, 17.5 \mathrm{~mm}$ ) towards $30 \%$ EA: Hex chromatographic eluents (Ef11) with lowest MIC values, e. i $60 \mu \mathrm{g}$ and $30 \mu \mathrm{g}$ respectively. Two chromatographic fractions, Ef11 and Ef13 were

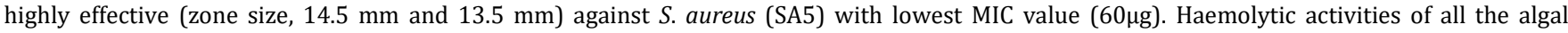
extracts were noticed that both $\mathrm{Eu}(\mathrm{EtOH})$ and methanolic extract, $\mathrm{Eu}(\mathrm{MeOH})$ of Euglena gives negative results.

Conclusion: These findings suggest that the extract obtained from E. viridis have active substances contributing to the increasing antibacterial potential.

Keywords: Alkaloid, Antibacterial activity, Minimum inhibitory concentration, Phytochemical screening, Staphylococcus aureus

(C) 2018 The Authors. Published by Innovare Academic Sciences Pvt Ltd. This is an open access article under the CC BY license (http://creativecommons.org/licenses/by/4.0/) DOI: http://dx.doi.org/10.22159/ijpps.2018v10i9.28324

\section{INTRODUCTION}

Antibiotics are naturally occurring or synthetic organic compounds which inhibit or destroy selective bacteria, generally at low concentrations [1]. The success of antibiotics against diseasecausing microbes is among modern medicines' great achievements. However, this kind of drug is beginning to lose its usefulness due to the development of resistance on the part of microbes. The increasing resistance of bacteria to antibiotics is kindled due to the misuse and over-prescription of the drugs. As resistance to antibiotics spreads, the development of new antimicrobial agents has to be expedited if the problem is to be contained. Thus the search for newer sources of antibiotics is a global challenge preoccupying research institutions, pharmaceutical companies and academia [2]. In the face of this scenario, the search for substances from natural sources, including algae, has been gaining importance in the pharmaceutical companies. The use of medicinal plants for therapy is an ancient practice. Though much work has been done on ethnomedicinal plants, there is still need to seek plants with medicinal value to combat diseases. More recently, some researchers have envisioned the enormous possibilities of algae and microalgae as potential source of bioactive compounds; particularly, some microalgae have been studied as a potential natural source of different functional compounds [3]. Recently, much attention has been focused on the microalgae as sources of the novel, biologically active compounds such as phycobiline, phenols, terpenoids, steroids and polysaccharide [4]. Freshwater algae are a rich source of structurally novel and biologically active metabolites. Primary or secondary metabolites produced by these organisms may be potential bioactive compounds of interest in the pharmaceutical industry. To date, many chemically unique compounds with various biological activities have been isolated and some of them are under investigation and are being used to develop new pharmaceuticals.

Euglena viridis is unicellular flagellate algal protists which are both freshwater and marine forms and the term 'Euglena' is coined by Ehrenberg [5]. The genus Euglena is the largest in the class Euglenophyceae with 154 or more species and it is the most interesting genus, which is a representative of the animal as well as plant character [6]. It is usually free-swimming fusiform, elongate, lanceolate, spindle-shaped, flexible unicellular mobile form with usually one or rarely two flexible flagella issuing out of an anterior notch at the base of which is an oval aperture and distinctive red pigment spot known as eye-spot. Euglena forms red blooms in all type of water bodies when density is very high characterized by the formation of haematochrome during bright sunny days. The coloration is green in cloudy days [7]. Euglena sp. has a broad range of medicinal properties, such as antimicrobial, anti-mutagenic, antiHIV, immunostimulant and cytotoxic activity [8-12]. It has been reported that the unicellular flagellate $E$. gracilis is a rich source of $\beta$ 1,3 , glucan and has applications in human and veterinary medicine as an immunostimulant and immunopotentiator [13].

The microalgae have a significant attraction as a natural source of bioactive molecules because they have the potential to produce bioactive compounds in culture, which are difficult to produce by chemical synthesis [14]. Despite this potential, attention has been centered on marine algae, with very little on freshwater algae. Recently the antibacterial activity of some freshwater algae has been studied [15-17].

As an efficient strategy of the investigation, organic solvents have been used to extract the possible active principles from the 
freshwater alga, Euglena. The present research was performed with an algal extract consisting of several substances; the derivative was initially analyzed for the phytochemical characteristics of its constitution through the phytochemical screening and chromatographic profile and aimed at exploring their antimicrobial activity and biomolecules of potential therapeutic interest.

The present study was to undertaken to evaluate the protective effects of various extracts of freshwater microalgae and its comparison with active principle haemolytic and antibacterial activity and biomolecules of potential therapeutic interest.

\section{MATERIALS AND METHODS}

\section{Chemicals and equipments}

All chemicals were of analytical reagent grade and obtained from SRL and Himedia. Among the equipment used: a rotary evaporator (Büchi), UV-Visible single beam spectrophotometer, Biorad.

\section{Processing of algal material}

Samples of freshwater alga, E. viridis were collected from ponds of Central Institute of Freshwater Aquaculture, Bhubaneswar, India in the month of October 2012. All samples were brought to the laboratory in plastic bags containing pond water and then washed three times with distilled water to separate potential contaminants. The alga was identified as belonging to family Euglenophyceae following Records of Botanical Survey of India $[7,8]$.

\section{Preparation of the extracts}

Harvested samples were dried at room temperature and ground in an electric grinder. The resulting powder was submitted to lipid soluble polar solvents (hexane, ethyl acetate, ethanol, and methanol) for extraction, using a soxhlet extractor at $55-60{ }^{\circ} \mathrm{C}$. All samples were refluxed until saturation $(24 \mathrm{~h})$ and the respective extracts were dried in a rotary evaporator (Büchi) at low pressure. Subsequently, the residual extracts were suspended in the

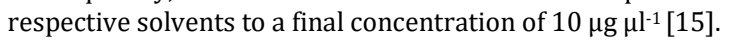

\section{Preliminary phytochemical screening}

The phytochemical screening of the crude extracts of E. viridis was performed to verify the presence of natural chemical constituents such as: alkaloids, flavonoids, tannin, steroids, reducing sugar and saponins by using standard methods of Sofowara and Trease and Evans $[18,19]$.

\section{Fractionation by column chromatography}

The active crude ethanolic extract of Euglena (2.0g) was fractionated using silica gel (SRL, 100-200 mesh size) column chromatography [20]. The solvent system was fixed by a preliminary thin layer chromatographic (TLC) study [21]. The elution was carried out successively with hexane, different ratio of ethylacetate/hexane $(1: 20,1: 5,1: 1,4: 5)$ and ethanol and $50-100 \mathrm{ml}$ of each fraction were collected. Then the fractions were reduced to $5 \mathrm{ml}$ by distilling. After distillation collected fractions were mixed according to their TLC behavior.

\section{Thin layer chromatography (TLC)}

Different fractions of ethanolic extract was developed by using different solvents in successions starting with the least polar and then shifting to the optimal solvent/solvent mixture, hexane, mixture of ethyl acetate and hexane (1:10, 1:5, 3:10, 1:1, 7:10) and chloroform/methanol. The developed application spots were visualized by sprayed with methanol and sulphuric acid (9.5:0.5) solution followed by heating the plates at $100{ }^{\circ} \mathrm{C}$ in an oven. To compare the results, the retention factor, $\mathrm{R}_{\mathrm{f}}$ value was determined for each substance. It was calculated as the ratio of the distance covered by the sample component to that covered by the solvent. Due to that, $\mathrm{R}_{\mathrm{f}}$-value is always between 0 and 1 .

\section{Test organisms}

Antibacterial sensitivity was tested against the pathogenic gramnegative strains of Aeromonas hydrophila (MTCC 646, ATCC 49140), Psedomonas putida (ATCC 49828), P. aeruginosa (MTCC 35672), Flavobacterium columnare (FLV1-FLV12) and gram-positive strains of Staphylococcus aureus (SA1-SA10 and a reference strain, ATCC6538P). Above culture was maintained in the Aquatic Animal Health Division, CIFA, Bhubaneswar, were taken for the antibacterial sensitivity study. The bacterial pathogens used in this work (other than reference strains) were isolated from diseased fish and human beings (table 1). Pure cultures of different bacterial strains were taken and inoculated in brain heart infusion (BHI) broth (Himedia, India) and incubated at $37^{\circ} \mathrm{C}$ for $18 \mathrm{~h}$.

Table 1: Isolated bacteria from different sources

\begin{tabular}{|c|c|c|c|c|}
\hline S. No. & Bacteria code & Species & Organ & Area of isolation \\
\hline & Staphylococcus aureus & & & \\
\hline 1 & SA1 & Goldfish & Eye & Private farm, Khurda \\
\hline 2 & SA2 & Goldfish & Eye & Private farm, Khurda \\
\hline 3 & SA3 & Catfish & Kidney & Private farm, Bhubaneswar \\
\hline 4 & SA4 & Rohu & Skin & Private farm, Puri \\
\hline 5 & SA5 & Rohu & Eye & Private farm, Pipili \\
\hline 6 & SA6 & Goldfish & Liver & CIFA, Bhubaneswar \\
\hline 7 & SA7 & Silver carp & Eye & CIFA, Bhubaneswar \\
\hline 8 & SA8 & $15 \mathrm{~d}$ old baby & Nose & Capital Hospital, Bhubaneswar \\
\hline 9 & SA9 & 20 d old baby & Nose & Capital Hospital, Bhubaneswar \\
\hline 10 & SA10 & 25 d old baby & Skin & Capital Hospital, Bhubaneswar \\
\hline 12 & Flavobacterium columnare & Rohu & Gill & CIFA research pond \\
\hline
\end{tabular}

\section{Inhibitory effect by the disc diffusion method}

Growth inhibition by pathogens by various crude extracts as well as fractions of the E. viridis was investigated using the disc diffusion method [22]. All bacteria were grown in nutrient broth $\left(10^{7} \mathrm{CFU} \mathrm{ml}-\right.$ ${ }^{1}$ ), incubated at $37^{\circ} \mathrm{C}$ for $24 \mathrm{~h}$ and plated using a sterile swab, on to petridishes containing antibiotic assay medium (Hi-media, Mumbai). At the same time, crude extract embedded discs $\left(10 \mathrm{mgml}^{-1}\right)$ and control (methanol) disc were allowed to air dry. After solvent evaporation, the discs were put on the above agar plates inoculated with the test bacteria and incubated at $37^{\circ} \mathrm{C}$. Activity of the algal extracts against bacterial pathogens was determined after $24 \mathrm{~h}$ at 37 ${ }^{\circ} \mathrm{C}$ by measuring the diameter of the halo around the discs [23]. The antibacterial activities of algal extracts were compared with inhibition zones around six commercial antibacterial discs i.e., bacitracin, gentamicin, clotrimazole, tetracycline, furazolodone and cephalaxin (Hi Media, India) that were used as references.

\section{Minimum inhibitory concentration (MIC)}

A broth tube dilution method was used to determine the minimum inhibitory concentration (MIC) [24]. The extracts of Euglena viridis were serially diluted in nutrient broth. Equal amount $(2 \mathrm{ml})$ of bacterial suspension corresponding to $10^{7} \mathrm{CFU}$ ml-1 of the test organism was added to each of the test tubes. The mixture was allowed to overnight incubation and the turbidity in each tube was visualized. The highest dilution of the algal extract in which there was no growth of the organism on the nutrient broth was observed. 


\section{Haemolytic activity}

Haemolytic activity was carried out by using blood agar plate method. The crude algal extracts were used to detect the haemolytic activity. The blood agar plates were prepared by adding human blood $(5 \%)$ to blood agar base. Wells were punched on the blood agar surface by using a gel borer. The algal extracts were prepared $1000 \mu \mathrm{g} / \mathrm{ml}$ concentration, and a volume of $100 \mu \mathrm{l}$ was transferred aseptically into the well. Then plates were incubated at $37^{\circ} \mathrm{C}$ for 12 $\mathrm{h}$. The plates were then examined for the zone of haemolysis [25]

\section{Statistical analysis}

The results were analyzed using one-way analysis of variance (ANOVA) and significant difference of among various extracts of Euglena was compared using duncan's multiple range test (DMRT) [26].

\section{RESULTS AND DISCUSSION}

An alternative to the inhibition of bacterial growth would lie in an approach to prevent pathogens from establishing a successful infection that can be done through developing new antipathogenic drugs. The most important of these bioactive constituents of plants are alkaloids, tannin, flavonoid and phenolic compounds [27]. Successful prediction of botanical compounds from plant material is largely dependent on the type of organic solvent used in the extraction procedure. In our study we are using four crude extracts, $\mathrm{E}(\mathrm{Hex}), \mathrm{E}(\mathrm{EtAC}), \mathrm{E}(\mathrm{EtOH})$ and $\mathrm{E}(\mathrm{MeOH})$ of E. viridis and we are concentrating on crude as well as fractions of ethanolic extracts. The preliminary phytochemical analysis of the Euglena extract revealed the presence of alkaloid, flavonoids, steroid and reducing sugar presented in table 2. The ethanolic extract posses alkaloid, flavonoid, steroid and reducing sugar [28]. Similar type of observations was found by many workers [29] that the ethanolic extract of plants (Plectranthus glandulosis) shows the presence of tannins, alkaloids, glycosides, steroids, and flavonoids. Six steroids have been isolated from an ethanolic extract of green alga Chaetomorpha basiretorsa Setchell [30]. Bhaigyabati et al. reported that various solvent extracts of marine seaweed Sargassum muticum posses steroids, alkaloids, flavonoids and carbohydrates with antioxidant activities [31].

Table 2: Preliminary phytochemical tests of various extracts of $E$. viridis

\begin{tabular}{|c|c|c|c|c|}
\hline Constituents/Test & E(Hex) & E(EtAC) & E(EtOH) & $\mathrm{E}(\mathrm{MeOH})$ \\
\hline \multicolumn{5}{|l|}{ Alkaloid } \\
\hline Dragendroff & - & + & + & - \\
\hline Wagner & - & + & + & - \\
\hline Mayer & - & + & + & - \\
\hline \multicolumn{5}{|l|}{ Tanin } \\
\hline Ferric chloride test & - & - & - & - \\
\hline \multicolumn{5}{|l|}{ Flavonoids } \\
\hline $\mathrm{NaOH}$ and dil. HCL & - & + & + & - \\
\hline Steroid & - & - & + & - \\
\hline Saponins & - & - & - & + \\
\hline \multicolumn{5}{|l|}{ Reducing sugar } \\
\hline Fehling & - & - & + & - \\
\hline
\end{tabular}

Note: $(+)=$ present; $(-)=$ absent

The antibacterial effect of crude extract of E. viridis was already demonstrated by our previous work $[8,15]$. In our previous work, it was reported that the chloroform, acetone, methanol and ethanol extracts of E. viridis showed antibacterial activity against different fish pathogens [8]. In the present study, the crude and chromatographic fractions of Euglena were screened against gram+ve and gram-ve bacteria. Among four crude extracts, ethanolic, $\mathrm{Eu}(\mathrm{EtOH})$ and methanolic, $\mathrm{Eu}(\mathrm{MeOH})$ extracts showed high inhibiting activity against selected bacterial pathogens, whereas two strains of $F$. columnare (FLV5, FLV6), 7 strains of $S$. aureus (SA7, SA8, SA9, SA10 and ATCC 6538P), P. putida, ATCC 49128 and A. hydrophila, MTCC 646 were resistant towards the low polar extracts i. e hexane, Eu(Hex) and ethyl acetate, Eu(EtAC) (table 3, 4 and fig. 1), The ethanolic extract, Eu(EtOH) poses significantly ( $\mathrm{p} \leq 0.5)$ higher zone of inhibition $\left(14.0 \pm 0.28^{\mathrm{a}}, 13.5 \pm 0.28^{\mathrm{a}} \mathrm{mm}\right)$ against FLV8 and FLV9 respectively (table 3). Earlier studies showed that the methanol extract of green seaweed Cladophora glomerata was active against gramnegative bacteria. Ethanol extract also inhibited gram-positive bacteria Bacillus cereus $(16.7 \mathrm{~mm}), \quad B . \quad$ megaterium $(17.2 \mathrm{~mm}), \quad B$. stearothemophilus (15.9 mm), B. subtilis (13.4 mm), S. aureus $(12.9 \mathrm{~mm})$, and $S$. faecalis $(13.5 \mathrm{~mm})$. In the present study, we observed that both ethanolic and methanolic extracts were active against gram-negative bacteria. The variation of the antibacterial activity of our extracts might be due to the presence of antibacterial substances, which varied from species to species [32].

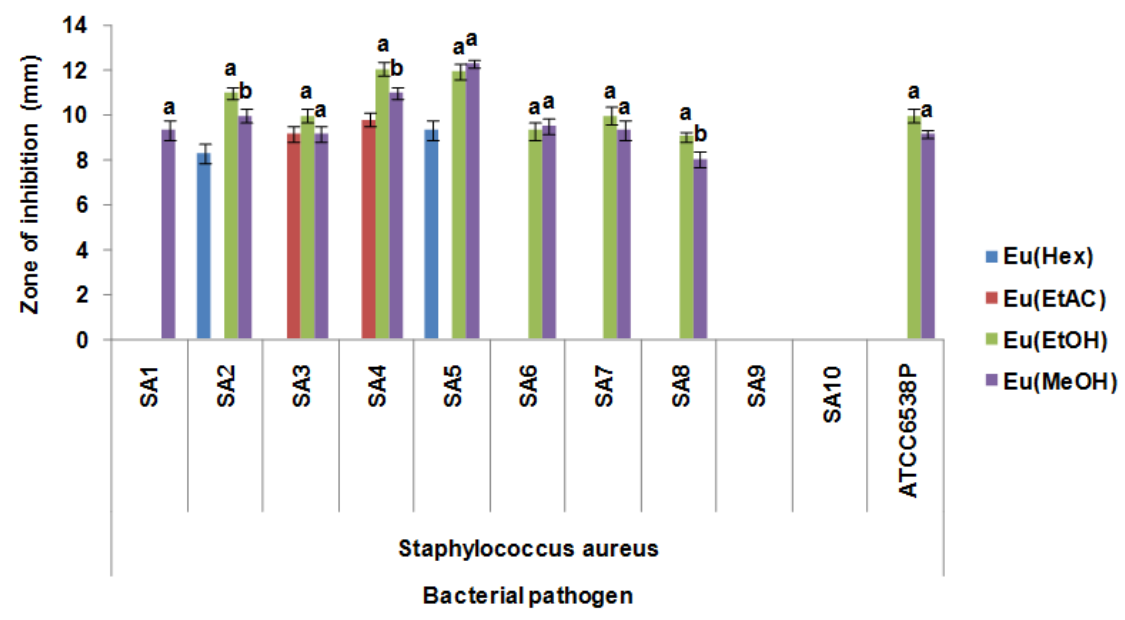

Fig. 1: Antibacterial activity of various extracts of ethanolic extracts of Euglena against different strains of $S$. aureus. Each value represents the mean $\pm S D(n=3)$. Bars with different letters indicate activities significantly different $(p \leq 0.05)$ 
The crude extracts of $E$. viridis were partially purified by silica gel column chromatography using hexane: ethyl acetate as solvent systems. A total of sixteen different fractions were obtained and details of the fractions were represented in table 5 . All the fractions were assayed for antibacterial activity against an array of pathogens and summarized (fig. 2 and 3). Based on the preliminary screening results, five selected fractions, Ef4, Ef5 (5\% EA/Hex); Ef8 (10\% EA/Hex); Ef11, Ef13 (30\% EA/Hex) and crude ethanolic extract of Euglena were chosen to determine the MIC values against 12 gramnegative and 11 gram-positive bacterial pathogens.

Table 3: Antibacterial activities of various extracts of Euglena against different strains of $F$, columnare

\begin{tabular}{|c|c|c|c|c|c|c|c|c|c|c|c|c|}
\hline \multirow[t]{3}{*}{ Extracts } & \multicolumn{12}{|c|}{ F. columnare } \\
\hline & \multicolumn{12}{|c|}{ Zone of Inhibition in $\mathrm{mm}$} \\
\hline & FLV1 & FLV2 & FLV3 & FLV4 & FLV5 & FLV6 & FLV7 & FLV8 & FLV9 & FLV10 & FLV11 & FLV12 \\
\hline \multirow[t]{2}{*}{$\mathrm{Eu}(\mathrm{Hex})$} & 0 & 0 & 9.0 & 9.5 & 0 & 0 & 10.0 & 11.0 & 11.2 & 10.2 & 9.0 & 0 \\
\hline & & & $\pm 0.28^{\mathrm{b}}$ & $\pm 0.5^{b}$ & & & $\pm 0.5^{\mathrm{b}}$ & $\pm 0.5^{b}$ & $\pm 0.33^{\mathrm{b}}$ & $\pm 0.33^{\mathrm{b}}$ & $\pm 0.28^{\mathrm{c}}$ & \\
\hline \multirow[t]{2}{*}{$\mathrm{Eu}(\mathrm{EtAC})$} & 10.0 & 9.3 & 9.2 & 8.6 & 0 & 0 & 0 & 10.3 & 11.5 & 10.9 & 8.5 & 9.0 \\
\hline & $\pm 0.28^{\mathrm{b}}$ & $\pm 0.44^{\mathrm{a}}$ & $\pm 0.33^{\mathrm{b}}$ & $\pm 0.44^{\mathrm{b}}$ & & & & $\pm 0.44^{\mathrm{b}}$ & $\pm 0.28^{\mathrm{b}}$ & $\pm 0.33^{\mathrm{b}}$ & $\pm 0.28^{c}$ & $\pm 0.5^{\mathrm{b}}$ \\
\hline \multirow[t]{2}{*}{$\mathrm{Eu}(\mathrm{EtOH})$} & 12.3 & 7.8 & 10.0 & 12.5 & 9.0 & 11.2 & 11.3 & 14.0 & 13.0 & 11.0 & 11.0 & 11.0 \\
\hline & $\pm 0.44^{\mathrm{a}}$ & $\pm 0.16^{\mathrm{b}}$ & $\pm 0.28^{\mathrm{b}}$ & $\pm 0.28^{\mathrm{a}}$ & $\pm 0^{\mathrm{b}}$ & $\pm 0.33^{\mathrm{a}}$ & $\pm 0.44^{\mathrm{a}}$ & $\pm 0.28^{\mathrm{a}}$ & $\pm 0.28^{\mathrm{a}}$ & $\pm 0.28^{\mathrm{b}}$ & $\pm 0.16^{\mathrm{a}}$ & $\pm 0.28^{a}$ \\
\hline \multirow[t]{3}{*}{$\mathrm{Eu}(\mathrm{MeOH})$} & 11.3 & 9.3 & 11.6 & 12.5 & 10.3 & 9.0 & 8.3 & 10.8 & 12.5 & 13.3 & 10.0 & 10.5 \\
\hline & $\pm 0.44^{\mathrm{a}}$ & $\pm 0.44^{\mathrm{a}}$ & $\pm 0.44^{\mathrm{a}}$ & $\pm 0.28^{\mathrm{a}}$ & $\pm 0.44^{\mathrm{a}}$ & $\pm 0.28^{\mathrm{b}}$ & $\pm 0.44^{\mathrm{c}}$ & $\pm 0.44^{\mathrm{b}}$ & $\pm 0.28^{\mathrm{a}}$ & $\pm 0.44^{\mathrm{a}}$ & $\pm 0.28^{\mathrm{b}}$ & $\pm 0.5^{\mathrm{a}}$ \\
\hline & \multicolumn{12}{|c|}{ Standard antibiotics } \\
\hline Bacitracin (10units) & ND & 13 & 13 & ND & 13.5 & 14 & 13 & 14 & 13.5 & ND & ND & ND \\
\hline Gentamicin(10mcg) & ND & 15 & 15.5 & ND & 15 & 16 & 15.5 & 15 & 15 & ND & ND & ND \\
\hline
\end{tabular}

Note: Zone represent mean \pm SD, Mean represents common superscript are not significant to each other along rows. E(Hex)-Hexane extract of Euglena, Eu (EtAC)-Ethyl acetate extract of Euglena, Eu(EtOH)-ethanolic extract of Euglena and Eu(MeOH)-methanolic extract of Euglena. Each value represents the mean $\pm S D(n=3)$. Lines with different letters indicate activities significantly different $(p \leq 0.05)$

Table 4: Antibacterial activities of various extracts of Euglena against reference strains of Pseudomonas spp. and A. hydrophila

\begin{tabular}{|c|c|c|c|c|}
\hline \multirow[t]{3}{*}{ Extracts $\left(10 \mathrm{mgml}^{-1}\right)$} & \multirow{2}{*}{\multicolumn{4}{|c|}{$\begin{array}{l}\text { P. putida } \quad \text { P. aeruginosa } \\
\text { Zone of Inhibition in } \mathrm{mm}\end{array}$}} \\
\hline & & & & \\
\hline & ATCC 49128 & MTCC 35072 & MTCC 646 & ATCC 49140 \\
\hline Eu (Hex) & 0 & $9.33 \pm 0.44^{b}$ & 0 & $9.50 \pm 0.28^{c}$ \\
\hline Eu (EtAC) & 0 & 0 & 0 & $10.0 \pm 0.28^{c}$ \\
\hline $\mathrm{Eu}(\mathrm{EtOH})$ & $11.33 \pm 0.44^{\mathrm{a}}$ & $9.66 \pm 0.16^{\mathrm{ab}}$ & $15.00 \pm 0.28^{a}$ & $12.00 \pm 0.28^{b}$ \\
\hline $\mathrm{Eu}(\mathrm{MeOH})$ & $9.66 \pm 0.44^{b}$ & $10.66 \pm 0.44^{b}$ & $10.66 \pm 0.44^{b}$ & $13.66 \pm 0.44^{\mathrm{a}}$ \\
\hline \multicolumn{5}{|l|}{ Standard antibiotics } \\
\hline Clotrimazole (10mcg) & 12 & 12 & 18 & ND \\
\hline $\begin{array}{l}\text { Tetracycline } \\
(20 \mathrm{mcg})\end{array}$ & 15 & 19 & ND & ND \\
\hline $\begin{array}{l}\text { Furazolodone } \\
\text { (50mcg) }\end{array}$ & 15 & 18 & ND & ND \\
\hline $\begin{array}{l}\text { Cephalaxin } \\
30 \mathrm{mcg}\end{array}$ & 9 & 8 & 15 & ND \\
\hline
\end{tabular}

Note: Zone represent mean \pm SD, Mean represents common superscript are not significant to each other along rows. E(Hex)-Hexane extract of Euglena, Eu (EtAC)-Ethyl acetate extract of Euglena, Eu(EtOH)-ethanolic extract of Euglena and Eu(MeOH)-methanolic extract of Euglena. Each value represents the mean $\pm S D(n=3)$. Lines with different letters indicate activities significantly different $(p \leq 0.05)$

\section{ND: Not done}

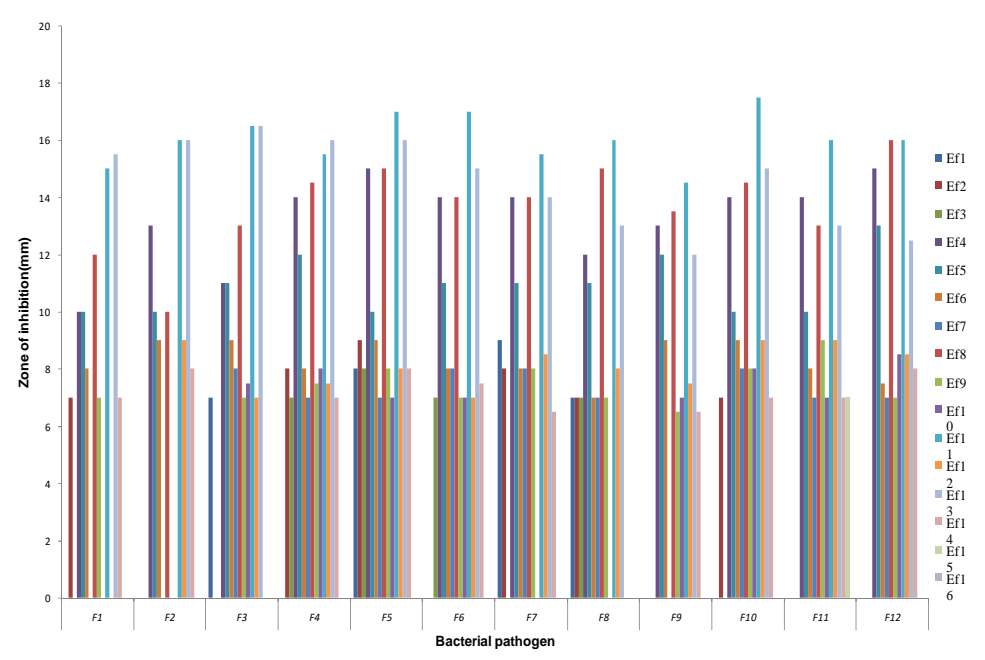

Fig. 2: Antibacterial activity of various fractions of ethanolic extracts of Euglena against different strains of $F$. columnare 


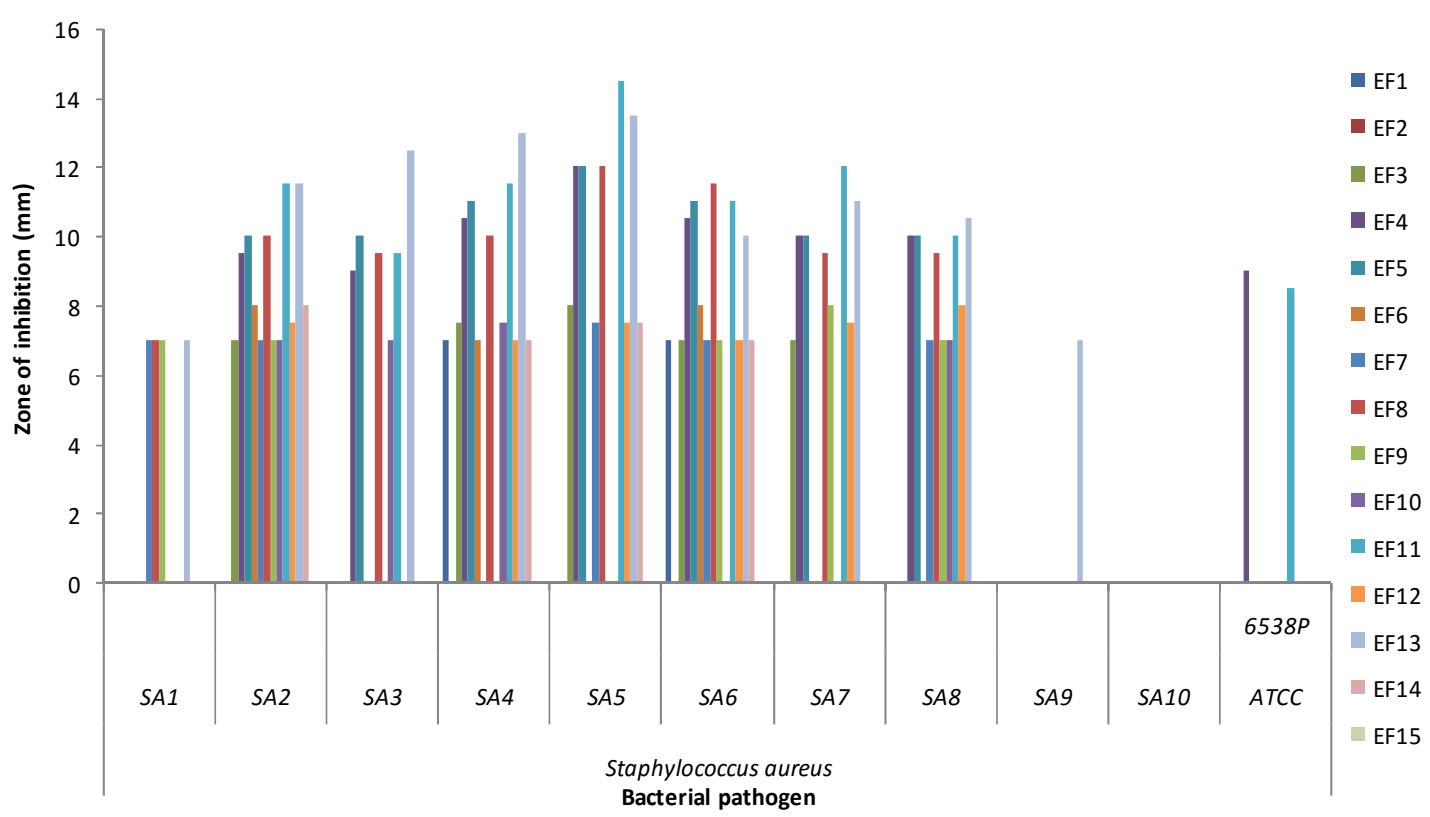

Fig. 3: Antibacterial activity of various fractions of ethanolic extracts of Euglena against different strains of $S$. aureus

Table 5: Showing silica gel (100-200 mesh) column chromatography fractionated $E$. viridis

\begin{tabular}{|c|c|c|c|c|c|}
\hline Sample fractionated & Extract used & Code of fractions & Weight of fractions (g) & Solvent for elution & TLC Rf values \\
\hline \multirow[t]{17}{*}{ Euglena viridis } & Ethanol (EtOH) & Ef1 & 1.0025 & Hex & $0.85,0.5,0.42,0.33$ \\
\hline & & Ef2 & 0.8421 & & $0.38,0.23$ \\
\hline & & Ef3 & 0.0227 & & $0.3,0.1$ \\
\hline & & Ef4 & 0.0138 & EA: Hex & $0.93,0.72,0.63,0.54$ \\
\hline & & Ef5 & 0.0142 & $(0.5: 9.5)$ & $0.95,0.66,0.53,0.32$ \\
\hline & & Ef6 & 0.0164 & & $0.86,0.80,0.54,0.31$ \\
\hline & & Ef7 & 0.0571 & $\begin{array}{l}\text { EA: Hex } \\
(1: 13.3)\end{array}$ & $0.81,0.53,0.33$ \\
\hline & & Ef8 & 0.0113 & EA: Hex & $0.91,0.50$ \\
\hline & & Ef9 & 0.0214 & $(1: 9)$ & $0.9,0.54,0.39$ \\
\hline & & Ef10 & 0.0338 & & 0.66 \\
\hline & & Ef11 & 0.1354 & EA: Hex & $0.75,0.65,0.50$ \\
\hline & & Ef12 & 0.15 & $(3: 7)$ & \\
\hline & & Ef13 & 0.0241 & & $0.65,0.51$ \\
\hline & & & 0.0816 & & $0.65,0.44,0.26,0.16$ \\
\hline & & Ef14 & 0.1865 & EA: $\operatorname{Hex}(1: 1)$ & 0.25 \\
\hline & & Ef15 & 0.2031 & EA & $0.44,0.51$ \\
\hline & & Ef16 & 0.0914 & $\mathrm{EtOH}$ & $0.46,0.76$ \\
\hline
\end{tabular}

The details of the antibacterial activity and MIC values are given in the table 6 and 7. The result showed that low, as well as polar chromatographic eluents, could effectively inhibit the growth of all the strains of $F$. columnare and S. aureus with MIC values range from
$30 \mu \mathrm{g}-200 \mu \mathrm{g}$. Three strains of Flavobacterium (FLV5, FLV6 and FLV10) were highly sensitive (zone size, $17 \mathrm{~mm}, 17.5 \mathrm{~mm}$ ) towards 30\% EA: Hex chromatographic eluents (Ef11) with lowest MIC values, e. i $60 \mu \mathrm{g}$ and $30 \mu \mathrm{g}$ respectively.

Table 6: MIC values of various fractions of ethanolic extracts of Euglena against different strains of F. columnare

\begin{tabular}{|c|c|c|c|c|c|c|c|c|c|c|c|c|}
\hline Fractions & \multicolumn{12}{|c|}{ F. columnare } \\
\hline \multicolumn{13}{|c|}{ MIC values $(\mu \mathrm{g})$} \\
\hline Ef4 & 200 & 100 & 200 & 150 & 100 & 60 & 100 & 150 & 150 & 150 & 100 & 100 \\
\hline Ef5 & 150 & 150 & 150 & 100 & 100 & 100 & 150 & 150 & 150 & 200 & 200 & 100 \\
\hline Ef8 & 150 & 150 & 150 & 100 & 60 & 100 & 60 & 60 & 100 & 100 & 150 & 60 \\
\hline Ef11 & 100 & 60 & 60 & 100 & 60 & 30 & 60 & 30 & 100 & 30 & 60 & 60 \\
\hline Ef13 & 60 & 30 & 60 & 60 & 60 & 30 & 100 & 100 & 150 & 60 & 100 & 100 \\
\hline $\mathrm{E}(\mathrm{EtOH})$ & $>200$ & $>200$ & 200 & 150 & 200 & $>200$ & $>200$ & 150 & 150 & 200 & 200 & 200 \\
\hline
\end{tabular}

Note: Ef1, Ef2, Ef3 (100\%Hex); Ef4, Ef5, Ef6 (5\% EA/Hex); Ef7 (7\% EA/Hex); Ef8, Ef9 (10\% EA/Hex); Ef10, Ef11, Ef12, Ef13 (30\% EA/Hex); Ef14 (50\% EA/Hex); Ef15 (100\%EA); Ef16 (100\% EtOH) 
Table 7: Antibacterial activities and MIC values of various fractions of ethanolic extracts of Euglena against different strains of $S$. aureus

\begin{tabular}{|c|c|c|c|c|c|c|c|c|c|c|c|}
\hline $\begin{array}{l}\text { Fractions (10 mg } \\
\mathrm{ml}^{-1} \text { ) }\end{array}$ & S. aure & & & & & & & & & & \\
\hline \multicolumn{12}{|l|}{ MIC values $((\mu \mathrm{g})$} \\
\hline Ef4 & $>200$ & 200 & 200 & 150 & 100 & 150 & 200 & 200 & $>200$ & $>200$ & $>200$ \\
\hline Ef5 & $>200$ & 150 & 150 & 100 & 100 & 100 & $>200$ & $>200$ & $>200$ & $>200$ & $>200$ \\
\hline Ef8 & 200 & 200 & 200 & 100 & 60 & 100 & $>200$ & $>200$ & $>200$ & $>200$ & $>200$ \\
\hline Ef11 & $>200$ & 150 & 150 & 100 & 60 & 150 & 150 & $>200$ & $>200$ & $>200$ & 200 \\
\hline Ef13 & $>200$ & 200 & 100 & 60 & 60 & 150 & 150 & 150 & $>200$ & $>200$ & $>200$ \\
\hline $\mathrm{E}(\mathrm{EtOH})$ & $>200$ & 150 & 100 & 100 & 60 & 150 & 200 & 200 & $>200$ & $>200$ & 200 \\
\hline
\end{tabular}

Note: Ef1, Ef2, Ef3 (100\%Hex); Ef4, Ef5, Ef6 (5\% EA/Hex); Ef7 (7\% EA/Hex); Ef8, Ef9 (10\% EA/Hex); Ef10, Ef11, Ef12, Ef13 (30\% EA/Hex); Ef14 (50\% EA/Hex); Ef15 (100\%EA); Ef16 (100\% EtOH)

Similar type of results showed that crude ethanolic and fractions of S. polyrrhiza could effectively inhibit the growth of $A$. hydrophila, three species of Pseudomonas, two Vibrio species, S. aureus and E. coli [28]. Two chromatographic fractions, Ef11 and Ef13 were highly effective (zone size, $14.5 \mathrm{~mm}$ and $13.5 \mathrm{~mm}$ ) against $S$. aureus (SA5) with lowest MIC value $(60 \mu \mathrm{g})$. Similarly, partial purified fractions of green seaweed, Cladophora glomerata showed broad-spectrum activity against the human pathogen and fish pathogens [33].

The antimicrobial sensitivity i.e. clotrimazole, tetracycline, furazolidone and cephalaxin (as antibacterial) are taken as control for comparing the activity of the solvent extracts of $E$. viridis to find out its efficacy and usefulness while developing a standard bioactive compound as an antimicrobial. The antimicrobial activity of crude extracts of Ulva fasciata and Chaetomorpha antennina against ten human pathogenic bacterial strains were done and their zone of inhibition compared with a standard antibiotic, tetracycline.

In our study, some of the bacterial strains weakly respond to crude extracts, whereas the fractions showed broad-spectrum activity against multiple strains. This might be due to masking of antibacterial activity by the presence of some inhibitory compounds or factors in the extractor synergism by the presence of some compounds or factors in the extract. The variation of the antibacterial activity of our algal extracts might be due to the distribution of antimicrobial substances, which varied from fraction to fraction of the crude extract. Similar type of observations was made by Zeb et al. [34] who found that fractionation of crude extracts tested enhanced their activity against both gram-negative as well as gram-positive pathogens.

The Gelidium acerosa, a rhodophytacontain large amount of valuable phytochemicals like sapononins, flavonoids and alkaloids etc., which are known for its medicinal uses [35]. Preliminary phytochemical screening of the crude extracts of Canavalia rosea revealed the presence of tannins, phlobatannins, saponins, flavonoids, alkaloids, cardiac glycosides and phenolics. The presence of these bioactive constituents is associated with the antimicrobial activity of the plant. Distribution of hydrocarbons among the studied algae showed a very interesting pattern in respect to geographical variations. The presence of methyl and hexyl groups could be a result of alkylation of hydrocarbons with methanol and hexane which was used in the extraction and purification process in the present study.

The ability to produce antimicrobial substances may be significant not only as a defensive instrument for the aquatic plants but also as a good source of the new bioactive compounds from a pharmaceutical point of view. A variety of solvents with different polarities were used for the extraction of this bioactive plant material. Here we are concentrating on the active phytochemicals present in the crude ethanolic as well as fractionated product of the E. viridis. Ethanol is considered as a safe solvent and ethanol turned out to be the most suitable solvent in extracting antioxidant components from Spirulina since ethanol extracts showed a high antioxidant activity together with a high extraction yield. The partially purified fractions need further purifications and the details of the chemical nature by GC MS and NMR spectra.

Subsequent experiments were conducted to determine the haemolytic activity was done, which is thought to be due to effects on cell membrane permeability by forming pores in membranes, altering the sodium-potassium and calcium-magnesium ATPase activities, or insertion of the hydrophobic saponin nucleus into the lipid bilayer. The haemolytic activity of methanolic extract and fraction exhibited both haemolytic and antibacterial activities against S. aureus, Lactobacillus spp., S. Typhimurium and E. coli. Among the various biological effects of saponins are haemolytic activity [36] and antibacterial activity. In contrast, from haemolytic activity test, it was noticed that both ethanolic and methanolic extract of Euglena poses no activity. Similar type of result was found in the methanolic extract of $L$. spiralis leaves, where it showed antioxidant, antimicrobial, antiproliferative activities but no haemolytic activity [37].

\section{CONCLUSION}

In conclusion, the present study provides data to show the appreciable antibacterial activity of freshwater alga E. viridis crude extracts and partial purified fractions against gram-positive human and fish pathogens as well as gram-negative fish pathogens. The result presumes that the secondary metabolites like alkaloids, flavonoids and reducing sugars may act as potential bioactive substance and can be exploited in pharmaceutical preparations. Further study is in progress to find out the mechanism of inhibition of gram-negative pathogens by the purified compounds.

\section{ACKNOWLEDGMENT}

The authors are grateful to the Indian Council Agricultural Research (ICAR), New Delhi and the Department of Science and Technology for providing the financial assistance.

\section{AUTHORS CONTRIBUTIONS}

All the author have contributed equally

\section{CONFLICT OF INTERESTS}

Declared none

\section{REFERENCES}

1. Brooks GF, Carroll KC, Butel JS. The growth and death of microorganism. In Jawetz, Melinick, Adelberg's Medical Microbiology. 24th ed Mcgraw-Hill Toronto; 2007. p. 57.

2. Latha S, Kannabiran K. Antimicrobial activity and phytochemicals of Solanum trinobatum Linn. Afr J Biotechnol 2006;5:2402-4.

3. Bhattacharjee M. Pharmaceutically valuable bioactive compounds of algae. Asian J Pharma Clin Res 2016;9:43-7.

4. Abd El-Baky HH, El Baz FK, El-Baroty GS. Evaluation of marine alga Ulva lactuca $L$. as a source of the natural preservative ingredient. Am Eurasian J Agric Environ Sci 2008;3:434-44.

5. Ehrenberg CG, Neue beobachtungen über blutartige erscheinungen in aegypten, arabien und sibirien, nebst einer uebersicht und kritik der früher bekannten. Annalen Der Physik Und Chemie Ser 1830;28:477-514.

6. Gojdics M. The Genus Euglena. University of Wisconsin Press, Madison. [Includes keys, descriptions, and fig. of all species known at the time]; 1953.

7. Biswas K. Common fresh and brackish water algal flora of India and Burma. Part I. Records of the Botanical Survey of India; 1949. p. 15. 
8. Das BK, Pradhan J, Pattnaik K, Samantray BR, Samal SK. Production of antibacterials from the freshwater alga Euglena viridis (Ehern). World J Microbiol Biotechnol 2005;21:45-50.

9. Foltinova $\mathrm{P}$, Lahitova N, Ebringer L. Antimutagenicity in Euglena gracilis. Mutation Res 1994;323:167-71.

10. Nakashima H, Ohshiro Y, Miyano N, Yamamoto N, Ichikawa S, Kondo $\mathrm{H}$, et al. Synergistic inhibition of human immunodeficiency virus type 1 (HIV-1) replication in vitro by sulphated paramylon and 3'-azido-2',3'-dideoxythymidine (AZT). Lett Appl Microbiol 2008; 18:24-6.

11. Das BK, PradhanJ, Sahu S. The effect of Euglena viridis on the immune system of rohu, Labeo rohita. Fish Shellfish Immunol 2009;26:871-6.

12. Das BK, Pradhan J, Mahammad S, Nayak KK. In vitro cytotoxic and antibacterial activity of ethanolic extract of Euglena viridis. Int J Pharma Bio Sci 2012;3:321-31.

13. Barsanti L, Vismara R, Passarelli V, Gualtieri P. Paramylon (b-1,3glucan) content in wild-type and WZSL mutant of Euglena gracilis effects of growth conditions. J Appl Phycol 2001;13:59-65.

14. Borowitzka MA, Borowitzka LJ. Vitamins and fine chemicals from microalgae. In: Microalgal Biotechnology press syndicate of the University of Cambridge, New York, USA; 1989.

15. Das BK, Pradhan J. Antibacterial properties of selected freshwater microalgae against pathogenic bacteria. Indian J Fish 2010;57:61-6.

16. Pradhan J, Sahu S, Nilima PM. Antibacterial properties of freshwater Microcystis aeruginosa (Kütz) to bacterial pathogen-a comparative study of bacterial bioassays. Indian J Anim Sci 2011;81:1266-7.

17. Pradhan J, Das BK, Sahu S, Mishra BK, Das BK. Traditional antibacterial activity of freshwater microalga Spirulina platensis to aquatic pathogens. Aquacult Res 2012;43:1287-95.

18. Sofowara A. Medicinal plants and traditional medicine in Africa. Spectrum Books Ltd, Ibadan, Nigeria; 1993. p. 289.

19. Trease GE, Evans WC. Pharmacognosy. 15 th Edn. Saunders; 2002. p. 214-393.

20. Motl O, Novotny L. Adsorption column chromatography. In: Laboratory Hand Book of Chromatography and Allied Methods. (Ed. by Mikis, O.) Ellis Horwoods Ltd. Chichester; 1979. p. 150217.

21. Stahl E. Apparatus and general technique in TLC, In: Thin Layer Chromatography. Ed. Stahl E. Springer Verlag, Berlin; 1969. p. 52-85.

22. Chabbert YA. L' antibiogramme. Sensibilite et resistancedes bacteries aux antibiotiques. De la Tourelle; 1963. p. 257.

23. Izzo AA, DiCarlo G, Biscardi D, De Fusco R. Biological screening of Italian medicinal plants for antibacterial activity. Phytother Res 1995;9:281-6.
24. Alderman D, Smith P. Development of draft protocols of standard reference methods for antimicrobial agent susceptibility testing of bacteria associated with fish disease. Aquaculture 2001;196:211-43.

25. Kumar G, Karthik L, Bhaskara Rao KV. In vitro anti-candida activity of Calotropis gigantea against clinical isolates of Candida. J Pharm Res 2010;3:539-42.

26. Duncan DB. Multiple range and multiple ' $F$ ' tests. Biometrics 1955;11:1-42.

27. Ayandele AA, Adebiyi AO. The phytochemical analysis and antimicrobial screening of extracts of Olax subscorpioidea. African J Biotechnol 2007;6:868-70.

28. Das BK, Das DP, Pradhan J, Priyadarshinee B, Sahu I, Roy P, Mishra BK. Evaluation of antimicrobial activity and phytochemical screening of ethanolic extract of greater duckweed, Spirodela polyrrhiza. Int J Pharma Bio Sci 2012;3:822-33.

29. Shihabudeen MS, Priscilla HD, Kavitha T. Antimicrobial activity and phytochemical analysis of selected Indian folk medicinal plants. Int J Pharm Sci Res 2010;1:430-4.

30. Dayong S, Xiao F, Jie S, Lijun H, Jiangong S. Steroids from green alga Chaetomorpha basiretorsa setchell. Chinese J Oceanol Limnol 2008;26:415-8.

31. Bhaigyabati T, Kirithika T, Shiny K, Usha K. Phytochemical screening and antioxidant activity of various extracts Ofsargassum muticum. Int J Pharm Res Dev 2011;3:25-30.

32. Lustigman B, Brown C. Antibiotic production by marine algae isolated from the New York/New Jersey Coast. Bull Environ Cont Toxicol 1991;46:329-35.

33. Yuvaraj N, Kanmani P, Satishkumar R, Paari KA, Pattukumar V, Arul V. Extraction, purification and partial characterization of Cladophora glomerata against multidrug-resistant human pathogen Acinetobacter baumannii and fish pathogens. World J Fish Mar Sci 2011;3:51-7.

34. Zeb A, Ali Z, Ahmad T, Abdulmanon A. Physiochemical characteristics of wheat varieties growing in the same and different ecological regions of Pakistan. Pakistan J Biol Sci 2006;9:1823-8.

35. Dhanalakshmi M, Angayarkanni J. Phytochemistry and antibacterial activity of chlorosarcinopsis species. Int J Sci Technol Res 2013;2:315-21.

36. Woldemichael GM, Wink M. Identification and biological activities of triterpenoid saponins from Chenopodium quinoa. J Agric Food Chem 2001;49:2327-32.

37. de Freitas Araujo MG, Hilario F, Vilegas W. Correlation among antioxidant, antimicrobial, hemolytic, and antiproliferative properties of Leiothrix spiralis leaves extract. Int J Mol Sci 2012;13:9260-77. 